\title{
SISTEM PENDUKUNG KEPUTUSAN PEMILIHAN DISTRIBUTOR DENGAN ANALYTICAL HIERARCHY PROCESS PADA TOKO HIJABKUMURAH
}

\author{
Toni Hutomo Putro ${ }^{1}$, Irawan Setiadi ${ }^{2}$, dan Endang Sulistyaniningsih ${ }^{3}$ \\ 1,2,3 Universitas Indraprasta PGRI \\ Jl. Raya Tengah No.80, RT.6/RW.1, Gedong, Kec. Ps. Rebo, Kota Jakarta Timur, DKI Jakarta 13760 \\ 1'tonihutomoputro@gmail.com, ${ }^{2}$ irawan.setiadi91@gmail.com, ${ }^{3}$ esulistyaniningsih@gmail.com
}

\begin{abstract}
ABSTRAK
Kemajuan teknologi memberikan peran penting dalam perkembangan budaya masyarakat. Proses cepat, efektif dan efisien telah menjadi standar yang penting dalam menentukan pemilihan distributor dalam menyalurkan keluar masuk barang. Pelaksanaan proses keluar dan masuk barang dalam sebuah toko yang masih menggunakan metode tradisional dapat memakan waktu dan sangat tidak efisien. Permasalahan yang dihadapi dalam pemilihan distributor adalah sulitnya dalam memilih distributor yang sesuai kebutuhan, efisiensi proses sirkulasi barang masuk yang terkendala dengan informasi ketidakakuratan distributor, proses pemilihan distributor yang masih manual, keterlambatan dalam pengiriman yang mengurangi pendapatan rata-rata harian, dan ketersediaan barang yang dimiliki oleh distributor yang mengakibatkan waktu tunggu yang lama untuk mendapatkan pasokan barang. Tujuan penelitian ini adalah merancang sistem pendukung keputusan pemilihan distributor dengan metode AHP untuk memudahkan pengelola dalam memilih distributor yang sesuai kebutuhan. Sistem keputusan menggunakan metode AHP karena memperhatikan konsistensi dalam penilaian sesuai dengan bobot yang diberikan. Penentuan bobot masing-masing kriteria berdasarkan nilai skala yang diberikan oleh pengambil keputusan dengan melihat relatif kepentingan dari setiap kriteria. Pemberian nilai skala dipengaruhi pilihan dari pengambil keputusan. Hasil pengujian model dengan menggunakan Uji Konsisten Rasio terhadap pemilihan distributor menghasilkan nilai CR sebesar 0,05 sehingga dapat dinyatakan bahwa penilaian kriteria pada sistem sudah konsisten, karena kurang dari $10 \%$.
\end{abstract}

Kata Kunci: Analytical Hierarchy Process (AHP), pemilihan distributor, sistem pendukung keputusan

\begin{abstract}
Technological advances play an essential role in the development of society's culture. The fast, effective and efficient process has become a necessary standard in determining the selection of distributors in distributing goods in and out. Carrying out the process of getting in and out of goods in a store that still uses traditional methods can be time-consuming and very inefficient. The problems faced in the selection of distributors are the difficulty in choosing the appropriate distributors, the efficiency of the incoming goods circulation process, which is constrained by inaccurate distributor information. The distributor selection process is still manual. Delivery delays reduce the average daily income, and the availability of goods owned by distributors results in long waiting times to get supplies. This study aims to design a decision support system for selecting distributors with the AHP method to facilitate managers in choosing the appropriate distributors. The decision system uses the AHP method because it pays attention to consistency in the assessment according to the weight given. The weight is determined by the scale value's the decision-maker by looking at the relative importance of each standard. The choice of the decision-maker has influenced the value of the scale. The results of model testing using the Consistent Ratio Test for the selection of distributors resulted in a CR value of 0.05. It can state that the criteria assessment in the system is consistent because it is less than 10\%.
\end{abstract}

Key Word: Analytical Hierarchy Process (AHP), distributor selection, decision support system

\section{PENDAHULUAN}

Penggunaan sistem aplikasi menggunakan metode AHP akan sangat mempermudah dalam pemilihan distributor. Hal ini disebabkan sistem perhitungan yang sangat praktis dan detil sehingga akan sangat memudahkan dalam melakukan klasifikasi distributor sebelum dipilih. Penggunaan metode AHP juga sangat menekankan konsistensi untuk setiap kriteria dan penilaian yang diberikan sehingga hasilnya akurat.

"Sistem pendukung keputusan adalah sebuah sistem yang dimaksudkan untuk mendukung para pengambil keputusan manajerial dalam 
situasi keputusan tidak terstruktur". (Yodi Pasaribu, 2019).

"AHP adalah sebuah metode untuk memeringkat alternatif keputusan dan memilih yang terbaik dengan beberapa kriteria". (M. Kaluku, 2017).

"Distributor berasal dari kata distribusi. Distribusi merupakan saluran untuk menyampaikan ke pasar atau kepada konsumen akhir”. (M. Holis, 2016).

"Basis data (Database) adalah kumpulan data berelasi yang disusun, diorganisasikan dan disimpan secara sistematik dalam media simpan komputer mengacu kepada metodemetode tertentu sedemikian rupa sehingga dapat diakses secara cepat dan mudah menggunakan program/aplikasi komputer untuk memproleh data dari basis data tersebut". (C. Pamungkas, 2017).

"UML (Unified Modeling Language) adalah sebuah "bahasa" yang telah menjadi standar dalam industri untuk visualisasi, merancang dan mendokumentasikan sistem piranti lunak. (Yuni Sugiarti, 2013).

"Java merupakan pemrograman yang bersifat lintas platform. Artinya, bahasa ini dapat dipakai untuk menyusun program pada berbagai sistem operasi (Linux,Windows, UNIX)". (Abdul Kadir, 2014)

"Netbeans merupakan sebuah aplikasi Integrated Development Environment (IDE) yang menggunakan Bahasa pemrograman Java dari Sun Microsystems yang berjalan

Sistem pendukung keputusan dengan menggunakan metode Analytical Hierarchy Proses dibuat bertujuan untuk menghasilkan referensi keputusan yang sangat sesuai dengan kondisi kebutuhan karena hasil perhitungannya sangat bergantung kepada variabel hitung yang ditentukan oleh pemegang keputusan itu sendiri.

\section{METODE PENELITIAN}

Penelitian dilakukan selama 3 bulan dari Januari 2021 sampai dengan Maret 2021, dilaksanakan di kantor operasional HIJABKUMURAH yang berada di
Perumahan Permata Depok, Jl. Safir M5/27, Depok. Penelitian diawali dengan studi lapangan terhadap kondisi saat ini yang kemudian dirangkum untuk masalah yang dihadapi. Studi literatur dilakukan untuk mendapatkan informasi terkait lalu dilanjutkan dengan menentukan tujuan dari penelitian. Pengumpulan data lapangan dilakukan dengan cara melakukan observasi objek dan wawancara terhadap pelaku terkait. Kemudian data diolah untuk mendapatkan hasil yang dituangkan dalam kesimpulan dan saran.

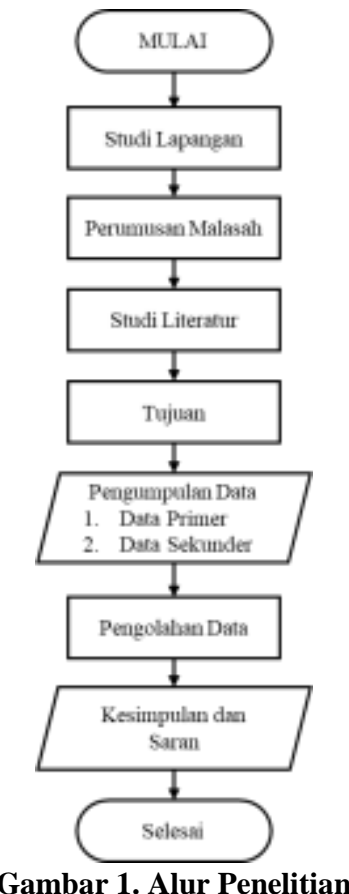

Mamik (2015:104) mengemukakan bahwa pada dasarnya ada beberapa cara untuk mengumpulkan informasi, yaitu: dengan cara Studi Lapangan meliputi: pertama, observasi yang menurut Widoyoko (2014:46) merupakan pengamatan dan pencatatan secara sistematis terhadap unsur-unsur yang nampak dalam suatu gejala pada objek penelitian.

Kedua, wawancara yang menurut Mamik (2015:108) wawancara adalah pertemuan yang langsung direncanakan antara pewawancara dan yang diwawancarai untuk memberikan atau menerima informasi tertentu. 


\section{Studi Lapangan}

Peneliti melakukan observasi dengan cara mengamati secara langsung sistem penjualan yang berjalan pada Online Shop HIJABKUMURAH. Penulis mengamati proses Pendataan Distributor mulai dari tahap permintaan data calon distributor sampai pencatatan pada buku jurnal. Kemudian penulis mengamati proses yang dilakukan Pemilik Toko dalam penilaian serta pemilihan distributor yang datanya sudah dimiliki. Penulis juga mengamati proses pengelolaan data distributor seperti pengkinian data, penghapusan data yang sudah tidak valid, dan lain-lain.

\section{Studi Literatur}

Peneliti menggunakan buku dan jurnal sebagai dokumen untuk pengumpulan data. Penulis juga melakukan pengecekan referensi menggunakan aplikasi Mendeley untuk jurnal guna memastikan referensi tersebut terdaftar. Metode pemilihan yang digunakan dalam penelitian adalah kualitatif, dimana pelaku terlibat sangat berpengaruh terhadap hasil yang akan didapatkan dari penelitian. Penggunaan metode Analytical Hierarchy Process melibatkan perhitungan terhadap kriteria yang sudah ditentukan diawal, menentukan data alternatif penilaian, teoriteori nilai perbandingan lalu dilakukan penghitungan, analisa dan hipotestis.

\begin{tabular}{|c|c|}
\multicolumn{2}{c}{ Tabel 1. Data Kriteria } \\
\hline NO & KRITERIA \\
\hline 1 & Harga \\
\hline 2 & Kualitas \\
\hline 3 & Ketersediaan \\
\hline 4 & Lokasi \\
\hline
\end{tabular}

Tabel 2. Data Alternatif

\begin{tabular}{|c|c|}
\hline KODE & NAMA \\
\hline B001 & PT. Aneka Hijab Indonesia \\
\hline B002 & PT. Muslim Eratama \\
\hline B003 & PT. Busana Nusantara \\
\hline B004 & Ayuna Mandiri \\
\hline B005 & Syakilla Hijab \\
\hline
\end{tabular}

Tabel 3. Data Perbandingan

\begin{tabular}{|c|l|}
\hline $\begin{array}{c}\text { INTENSITAS } \\
\text { KEPENTINGAN }\end{array}$ & \multicolumn{1}{c|}{ KETERANGAN } \\
\hline 1 & Kedua elemen sama pentingnya \\
\hline 3 & $\begin{array}{l}\text { Elemen yang satu sedikit lebih } \\
\text { penting daripada elemen yang } \\
\text { lainnya }\end{array}$ \\
\hline 5 & $\begin{array}{l}\text { Elemen yang satu lebih penting } \\
\text { daripada yang lainnya }\end{array}$ \\
\hline 7 & $\begin{array}{l}\text { Satu elemen jelas lebih mutlak } \\
\text { penting daripada elemen lainnya }\end{array}$ \\
\hline 9 & $\begin{array}{l}\text { Satu elemen mutlak penting } \\
\text { daripada elemen lainnya }\end{array}$ \\
\hline $2,4,6,8$ & $\begin{array}{l}\text { Nilai-nilai antara dua nilai } \\
\text { pertimbangan-pertimbangan yang } \\
\text { berdekatan }\end{array}$ \\
\hline
\end{tabular}

Perbandingan antar kriteria dibuat sesuai dengan parameter penilaian yang ditentukan oleh pemilik, dimana Harga lebih penting daripada Lokasi, serta Kualitas lebih penting daripada Harga dan Ketersediaan. Kualitas jauh lebih penting daripada Lokasi.

Tabel 4. Data Alternatif

\begin{tabular}{|c|c|c|c|c|}
\hline & HARGA & KUALITAS & KETERSEDIAAN & LOKASI \\
\hline HARGA & 1 & 0,333 & 0,333 & 3 \\
\hline KUALITAS & 3 & 1 & 3 & 8 \\
\hline KETERSEDIAAN & 3 & 0,333 & 1 & 3 \\
\hline LOKASI & 0,333 & 0,125 & 0,333 & 1 \\
\hline
\end{tabular}

Perbandingan alternatif dibuat dengan membandingkan data nilai yang diberikan pada tiap alternative untuk setiap kriteria yang sudah ditentukan. Penghitungan jumlah eigen ditentukan dengan penjumlahan nilai eigen, dimana penghitungan eigen merupakan hasil dari pembagian nilai untuk masing-masing kriteria dengan total pada kriteria tersebut. Penghitungan bobot prioritas kriteria dengan cara membagi jumlah eigen dengan banyaknya elemen (rata-rata).

HARGA: 0,594 / $4=0,148$

KUALITAS: 2,143 / $4=0,536$

KETERSEDIAAN: $1,009 / 4=0,252$

LOKASI: $0,253 / 4=0,063$

Lalu dilakukan perhitungan Konsistensi Matriks (CM), dimana penjumlahan hasil kali tiap bobot kriteria (Tabel 4.14) yang dikalikan dengan nilai rata-rata (Tabel 4.16) dan hasilnya kemudian dibagi dengan rata-rata pada tiap kriteria tersebut. 
Tabel 5. Perhitungan Bobot Prioritas dan Konsistensi Matriks

\begin{tabular}{|c|c|c|}
\hline & RATA-RATA & CM \\
\hline HARGA & 0,148 & 4,049 \\
\hline KUALITAS & 0,536 & 4,189 \\
\hline KETERSEDIAAN & 0,252 & 4,226 \\
\hline LOKASI & 0,063 & 4,167 \\
\hline
\end{tabular}

Penghitungan Konsistensi Rasio (CR) dilakukan dengan menentukan Konsistensi Index (CI). Setelah nilai Lamda Max diketahui, maka dilakukan penghitungan Konsistensi Indeks (CI), lalu melakukan penghitungan Konsistensi Rasio (CR) dengan tujuan memastikan apakah hasil perhitungan dapat dianggap konsisten. Rumus CR adalah Konsistensi Index (CI) dibagi dengan Indeks Random (IR), dimana nilai IR adalah 0,90 sesuai dengan table Indeks Konsistensi Random berikut dengan jumlah kriteria adalah 4 .

Tabel 6. Tabel Indeks Konsistensi Random (IR) \begin{tabular}{|l|l|l|l|l|l|l|l|l|l|l|l|l|l|l|l|}
\hline $\mathrm{n}$ & 1 & 2 & 3 & 4 & 5 & 6 & 7 & 8 & 9 & 10 & 11 & 12 & 13 & 14 & 15 \\
\hline
\end{tabular} \begin{tabular}{|l|l|l|l|l|l|l|l|l|l|l|l|l|l|l|l|}
\hline $\mathrm{RI}$ & 0.00 & 0.00 & 0.58 & 0.90 & 1.12 & 1.24 & 1.32 & 1.41 & 1.45 & 1.49 & 1.51 & 1.48 & 1.56 & 1.57 & 1.59 \\
\hline
\end{tabular}

$$
\begin{array}{ll}
\text { KONSISTENSI RASIO } \\
\text { RUMUS CI } & \text { (LAMDA MAX-N)/(N-1) } \\
\text { LAMDA MAX } & 4,157959 \\
\text { CI }= & 0,052653 \\
\text { RUMUS CR }= & \text { CI/IR } \\
\text { CR }= & 0,058504
\end{array}
$$

Setelah itu diperiksa apakah masih memenuhi konsistensi rasio yang diperbolehkan yaitu sama dengan atau kurang dari $10 \%$, apabila melebihi batas maka perbandingan antar elemen tidak konsisten dan perbandingan

\begin{tabular}{|c|c|c|c|c|c|c|}
\hline Alternatif & Harga & $\begin{array}{c}\text { Kualit } \\
\text { as }\end{array}$ & $\begin{array}{l}\text { Keters } \\
\text { ediaan }\end{array}$ & Lokasi & Nilai & Rank \\
\hline $\begin{array}{c}\text { Bobot } \\
\text { Prioritas } \\
\end{array}$ & 0,148 & 0,536 & 0,252 & 0,063 & & \\
\hline B001 & 0,359 & 0,409 & 0,285 & 0,054 & 0,348 & 1 \\
\hline B002 & 0,281 & 0,206 & 0,218 & 0,542 & 0,242 & 2 \\
\hline B003 & 0,194 & 0,192 & 0,153 & 0,106 & 0,177 & 3 \\
\hline B004 & 0,098 & 0,130 & 0,232 & 0,220 & 0,157 & 4 \\
\hline B005 & 0,068 & 0,063 & 0,111 & 0,079 & 0,077 & 5 \\
\hline
\end{tabular}
antar elemen dapat diulang. Dalam hal ini Konsistensi Rasio $=0,05<10 \%$, berarti masih memenuhi rasio konsistensi. Untuk tiap kriteria dilakukan langkah yang sama untuk menghitung prioritas dan konsistensi rasio.
Penyusunan rangking dilakukan setelah seluruh perhitungan selesai sesuai dengan langkah penghitungan bobot tiap kriteria.

\section{HASIL DAN PEMBAHASAN}

\section{USE CASE DIAGRAM}

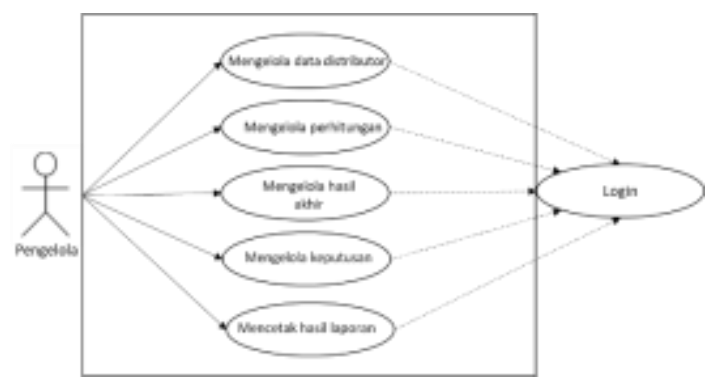

Gambar 2. Use Case Diagram

Use Case diagram dibuat dengan rancangan pengelola dapat melakukan aktivitas seperti pengelolaan data distributor, perhitungan, hasil akhir, keputusan, serta pencetakan hasil laporan.

\section{ACTIVITY DIAGRAM DATA DISTRIBUTOR}

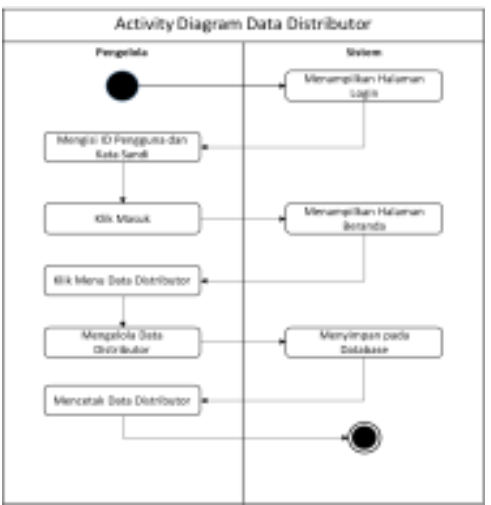

Gambar 2. Activity Diagram Data Distributor

Pengelola melakukan login dengan mengisi ID pengguna dan kata sandi, lalu masuk ke halaman beranda. Menekan tombol menu data distributor, mengelola data distributor lalu menyimpan pada database. Pengelola juga dapat mencetak data distributor pada akses yang sama. 


\section{SEQUENCE DIAGRAM DISTRIBUTOR}

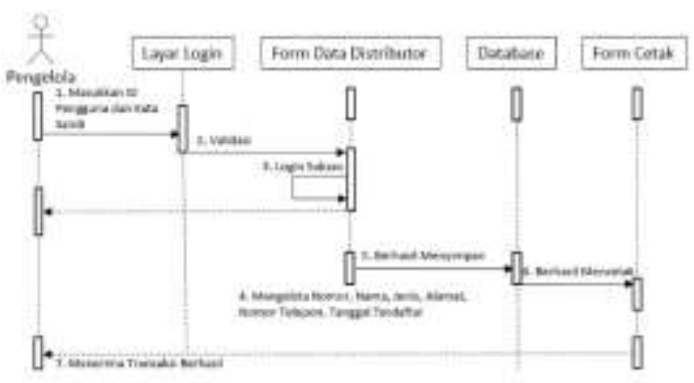

Gambar 4. Sequence Diagram Data Distributor

Pengelola melakukan login dengan mengisi ID pengguna dan kata sandi pada layar login, system akan melakukan validasi, jika login sukses lalu masuk ke halaman beranda. Menekan tombol menu data distributor, mengelola data distributor lalu menyimpan pada database. Pengelola juga dapat mencetak data distributor pada akses yang sama.

\section{CLASS DIAGRAM}

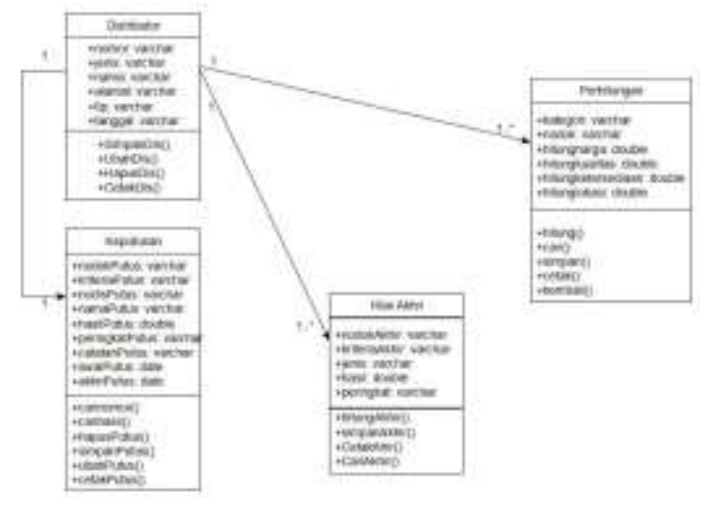

Gambar 5. Class Diagram

Class diagram dibuat sesuai dengan variabel yang dibutuhkan dalam perhitungan serta pengelolaan data distributor.

\section{ASPEK DALAM PERHITUNGAN AHP}

1. Data Kriteria

2. Data Alternatif

3. Nilai Perbandingan

4. Perbandingan Antar Kriteria

5. Perbandingan Antar Alternatif

6. Perhitungan Bobot

7. Penyusunan Ranking

Pengambilan keputusan dengan metode Analytical Hierarchy Process sangat memperhatikan konsistensi dalam penilaian sesuai dengan bobot yang diberikan. Penentuan bobot masing-masing kriteria berdasarkan nilai skala yang diberikan oleh pengambil keputusan dengan melihat relatif kepentingan dari masing-masing kriteria. Pemberian nilai skala dipengaruhi preferensi dari pengambil keputusan.

\section{TAMPILAN LAYAR}

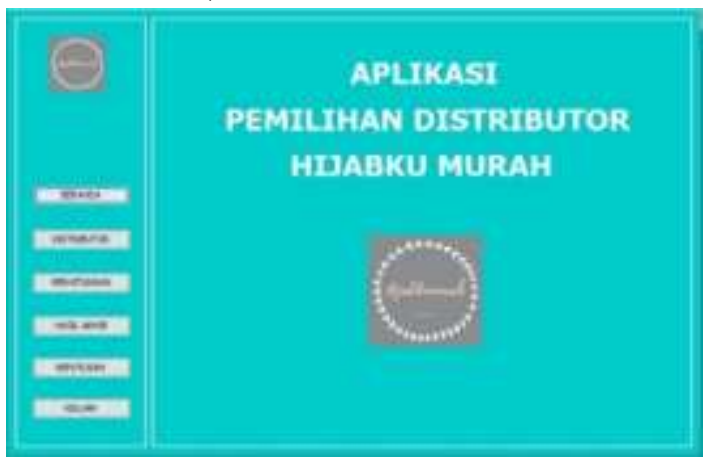

Gambar 6. Tampilan Beranda

Tampilan beranda ini terdapat beberapa icon menu yaitu distributor, perhitungan, hasil akhir, keputusan dan tombol keluar. Tampilan ini adalah awal untuk mengakses semua isi program.

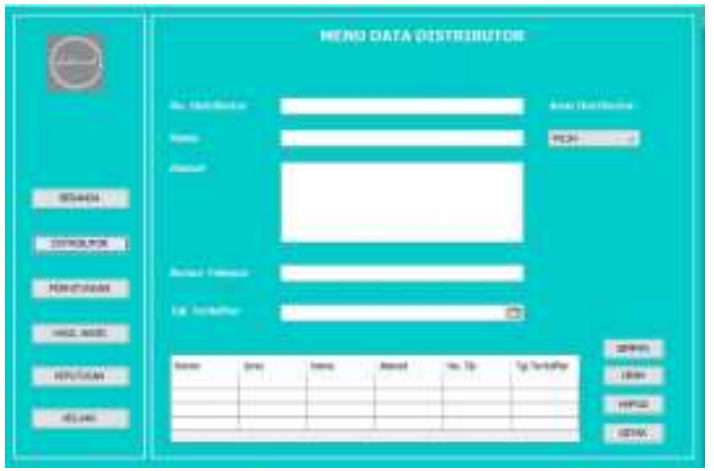

Gambar 7. Tampilan Menu Distributor

Pada tampilan ini, admin memasukkan datadata distributor sesuai isian form. Lalu klik simpan, setelah itu klik kembali untuk masuk ke tampilan beranda. Semua inputan akan tersimpan kedalam sistem.

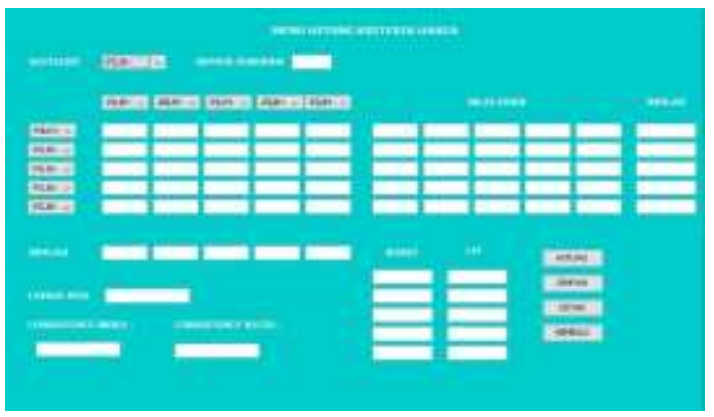

Gambar 8. Tampilan Perhitungan Harga 
Pada tampilan ini, admin memasukkan nilai akhir dari perhitungan antar distributor sesuai isian form. Lalu klik hitung, maka semua isian form akan terisi otomatis. Setelah itu klik simpan, semua inputan akan tersimpan kedalam sistem.

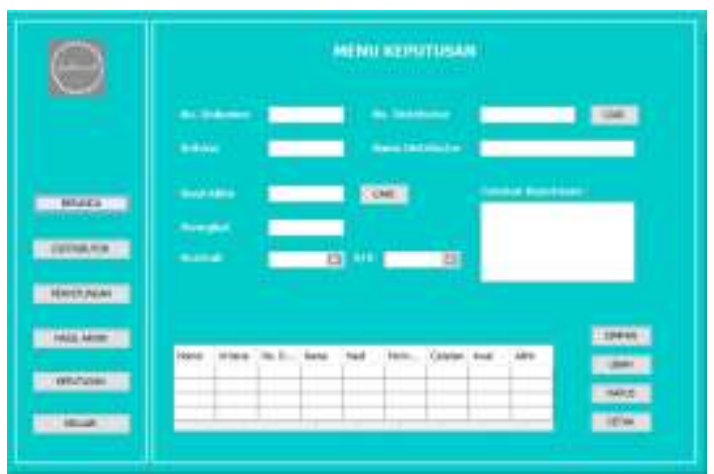

Gambar 9. Tampilan Menu Keputusan

Pada tampilan ini, admin memasukkan masing-masing nilai dari distributor sesuai isian form. Lalu klik cari, maka semua isian form akan terisi otomatis. Setelah itu isi hasil keputusan kontrak. Terakhir, klik simpan, semua inputan akan tersimpan kedalam sistem.

Pada tampilan form laporan keputusan ini berisi data-data yang ada pada tabel keputusan. Laporan muncul ketika admin mengklik tombol cetak pada tabel keputusan.

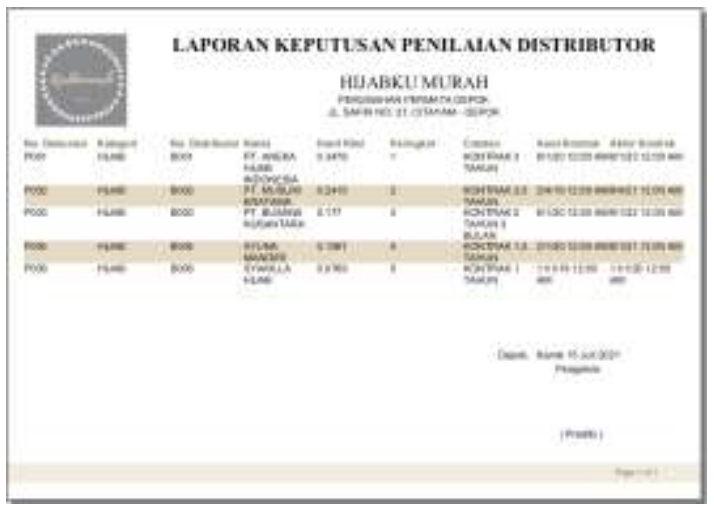

Gambar 10. Tampilan Laporan Keputusan

\section{PENGUJIAN DAN EVALUASI SISTEM}

Hasil pengujian model Sistem Pendukung Keputusan Pemilihan Distributor Dengan Metode Analytical Hierarchy Process menggunakan Uji Konsisten Rasio (Consistency Ratio) terhadap pemilihan distributor menghasilkan nilai $\mathrm{CR}$ sebesar 0,05 sehingga dapat dinyatakan bahwa penilaian kriteria sudah konsisten, karena kurang dari $10 \%$.

Metode yang diambil adalah metode pengujian Black Box. Pengujian Black Box adalah pengujian yang sistemnya tanpa memperhatikan struktur logika internal aplikasi. Metode ini digunakan untuk mengetahui apakah aplikasi tersebut berfungsi dengan benar. Pada metode ini data uji dibangkitkan, dieksekusi pada aplikasi dan kemudian keluaran dari aplikasi dicek apakah telah sesuai dengan yang diharapkan.

Berdasarkan hasil pengujian, ditarik kesimpulan bahwa aplikasi bebas dari kesalahan sintaks dan secara fungsional mengeluarkan hasil yang sesuai dengan yang diharapkan dan dapat berjalan dengan semestinya.

\section{SIMPULAN DAN SARAN}

Dengan dibuatnya aplikasi penunjang keputusan pemilihan distributor ini dapat dapat memudahkan toko dalam mengolah data dengan cepat dan akurat serta dapat memudahkan pencarian data dan di update dengan mudah. Aplikasi yang telah dibuat dengan bahasa pemrograman Java NetBeans dan penyimpanan data pada database MySQL dapat memberikan kelancaran dalam menginput dan penyimpanan data-data sehingga tidak terjadi kesulitan dalam pencarian data-data tersebut dalam proses penginputan maupun dalam pembuatan laporan.

Penggunaan metode AHP dapat diperluas jangkauannya dengan menambahkan metode penghitungan lain untuk menentukan parameter awal. Contohnya dalam menentukan perbandingan antar kriteria dengan menggunakan metode SAW (Simple Additive Weighing) sehingga hasil perhitungan yang dihasilkan akan jauh lebih akurat meskipun prosesnya akan menjadi semakin kompleks.

\section{UCAPAN TERIMAKASIH}

Rasa hormat dan ucapan terima kasih kepada semua pihak yang telah memberikan dukungan semangat untuk penulis dalam menyelesaikan penelitian ini, terutama kepada Jajaran pengurus Online Shop HIJABKUMURAH yang telah mengizinkan penulis untuk melaksanakan penelitian ini. 


\section{DAFTAR PUSTAKA}

Holis, M. (2016). Sistem Distribusi Dalam Perspektif Ekonomi Islam. Masharif AlSyariah, 1(2), 1-14. Retrieved from http://journal.umsurabaya.ac.id/index.php/Mas/article/vi ew/759/554

Ir. Yuni Sugiarti, M. Kom. (2013). Analisis \& Perancangan UML (Unified Modeling Language) Generated VB.6. Graha Ilmu, 30-45.

Kadir, A. (2014). Pengertian Sistem Informasi Menurut Abdul Kadir. In Pengenalan Sistem Informasi Edisi Revisi.

Kaluku, M. R. A., \& Pakaya, N. (2017). Penerapan Perbandingan Metode AhpTopsis Dan Anp-Topsis Mengukur Kinerja Sumber Daya Manusia Di Gorontalo. Ilkom Jurnal Ilmiah, 9(2), 124-131.

https://doi.org/10.33096/ilkom.v9i2.121 .124-131

Mamik. (2019). Metodologi Kualitatif. Jurnal Online Internasional \& Nasional Vol. 7 No.1, Januari - Juni 2019 Universitas 17 Agustus 1945 Jakarta. Retrieved from www.journal.uta45jakarta.ac.id

Pamungkas, C. A. (2017). Pengantar dan Implementasi Basis Data. In Pengantar dan Implementasi Basis Data (p. 68).

Pasaribu, Y. S. (2019). Sistem Pendukung Keputusan Pemilihan Hotel Bintang Lima Terbaik Di Kota Medan Menggunakan Metode Promethee. Jurnal Pelita Informatika, 7(3), 395-403. Retrieved from https://ejurnal.stmikbudidarma.ac.id/index.php/pelita/article /view/1150

Widoyoko. (2014). Jenis dan Desain Penelitian. Journal of Chemical Information and Modeling, 53(9), 46. 